\title{
Cytogenetic Characterization of the TM4 Mouse Sertoli Cell Line. II. Chromosome Microdissection, FISH, Scanning Electron Microscopy, and Confocal Laser Scanning Microscopy
}

\author{
Michael Schmid ${ }^{\mathrm{a}}$ Martina Guttenbach ${ }^{\mathrm{a}}$ Claus Steinlein ${ }^{\mathrm{a}} \quad$ Gerhard Wanner $^{\mathrm{b}}$ \\ Andreas Houben ${ }^{c}$ \\ a Department of Human Genetics, University of Wuerzburg, Wuerzburg, ${ }^{b}$ Biocenter, University of Munich, Munich, \\ and ${ }^{C}$ Leibnitz Institute of Plant Genetics and Crop Plant Research Gatersleben, Stadt Seeland, Germany
}

\section{Key Words}

Electron microscopy · FISH - Marker chromosomes .

Microdissection · Mouse Sertoli cell line · TM4

\begin{abstract}
The chromosomes and interphase cell nuclei of the permanent mouse Sertoli cell line TM4 were examined by chromosome microdissection, FISH, scanning electron microscopy, and confocal laser scanning microscopy. The already known marker chromosomes $m_{1}-m_{5}$ were confirmed, and 2 new large marker chromosomes $m_{6}$ and $m_{7}$ were characterized. The minute heterochromatic marker chromosomes $\mathrm{m}_{4}$ and $\mathrm{m}_{5}$ were microdissected and their DNA amplified by DOPPCR. FISH of this DNA probe on TM4 metaphase chromosomes demonstrated that the $\mathrm{m}_{4}$ and $\mathrm{m}_{5}$ marker chromosomes have derived from the centromeric regions of normal telocentric mouse chromosomes. Ectopic pairing of the $m_{4}$ and $\mathrm{m}_{5}$ marker chromosomes with the centromeric region of any of the other chromosomes (centromeric associations) was apparent in $\sim 60 \%$ of the metaphases. Scanning electron microscopy revealed DNA-protein bridges connecting the centromeric regions of normal chromosomes and the associated $\mathrm{m}_{4}$ and $\mathrm{m}_{5}$ marker chromosomes. Interphase cell nuclei of TM4 Sertoli cells did not exhibit the characteristic mor-
\end{abstract}

phology of Sertoli cells in the testes of adult mice as shown by fluorescence microscopy and confocal laser scanning microscopy.
Sertoli cells are somatic epithelial cells that adhere to the seminiferous tubules in mammalian testes. They are in close contact with spermatogenic cells, and their secretory activities are critical for the process of spermatogenesis. A variety of ion channels which are involved in secretory functions are expressed in Sertoli cells. Hormonal regulation by Sertoli cells involves multiple signaling pathways.

The clonal TM4 Sertoli cell line has been derived from immature BALB/c mouse testes [Mather, 1980]. In TM4 Sertoli cells a variety of features that are characteristic for normal Sertoli cells are conserved, like the responsiveness to follicle-stimulating hormone and lack of response to luteinizing hormone. Furthermore, the enzyme and receptor expression patterns, the physiological characteristics, and the response to a variety of substances resemble those found in Sertoli cells [Mather et al., 1982; Braunhut et al., 1990; Zengh et al., 1990; Akerstrom and Walters, 1992; Kumi-Diaka et al., 1998; Musa et al., 2000].

\section{KARGER 125}

(c) 2016 S. Karger AG, Base

$1424-8581 / 16 / 1473-0135 \$ 39.50 / 0$

E-Mail karger@karger.com

www.karger.com/cgr
Michael Schmid

Department of Human Genetics, University of Wuerzburg

Biozentrum, Am Hubland

DE-97074 Wuerzburg (Germany)

E-Mail m.schmid@biozentrum.uni-wuerzburg.de 
In a former cytogenetic analysis on this permanent TM4 mouse Sertoli cell line, conventional chromosome banding and spectral karyotyping were applied [Guttenbach et al., 2001]. The present study reports on the results obtained by chromosome microdissection, FISH, electron microscopy, and confocal laser scanning microscopy.

\section{Materials and Methods}

\section{Cell Culture, Chromosome Preparation and Staining} Techniques

Cell culture conditions and the technique for preparing metaphase chromosomes for brightfield microscopy were the same as in our previous study on TM4 cells [Guttenbach et al., 2001]. Chromosome preparations were stained according to the C-banding technique [Sumner, 1972] and by conventional DAPI staining $(0.2$ $\mu \mathrm{g} / \mathrm{ml}$ in McIlvaine buffer, $\mathrm{pH}$ 7.0). Fifty metaphases with C-banded chromosomes were examined.

\section{Chromosome Microdissection, DOP-PCR and FISH with the} DOP-PCR Products

A Zeiss Axiovert 35 inverted microscope equipped with a micromanipulator (5170, Eppendorf) was used for microdissection. Twenty marker chromosomes of the type $\mathrm{m}_{4}$ and $\mathrm{m}_{5}$, which are characteristic for TM4 cells were collected in a 1- $\mu$ l droplet containing proteinase $\mathrm{K}(0.5 \mathrm{mg} / \mathrm{ml}$; Boehringer, Mannheim $)$ in 10 $\mathrm{mM}$ Tris- $\mathrm{HCl}, \mathrm{pH} 8.0,10 \mathrm{~mm} \mathrm{NaCl}, 0.1 \%$ (w/v) SDS and overlaid with water-saturated paraffin oil. The DNA was amplified according to Pich et al. [1994] using the degenerate oligonucleotide primer MW-6 [Telenius et al., 1992]. The PCR amplification products were purified using a QIAquick-spin column (QIAGEN) and digoxigenin-labeled by nick translation. FISH was performed according to Guttenbach et al. [1996]. A total of 100 metaphases with clear hybridization signals were analyzed.

\section{FISH with Telomeric DNA Repeats}

For detection of telomeric (TTAGGG) n repeats in metaphase chromosomes, the synthetic deoxynucleotide oligomers (GGGTTA $)_{7}$ and (TAACCC) $)_{7}$ were used [Moyzis et al., 1988]. These were synthesized on an automated DNA synthesizer (Gene Assembler Plus, Pharmacia) and separately $3^{\prime}$ end-labeled with biotin16-dUTP using terminal deoxynucleotidyltransferase (Boehringer). Denaturation of the chromosome preparations, in situ hybridization and posthybridization washes, as well as detection of the hybridization probes were performed as described by Meyne et al. [1990].

\section{Scanning Electron Microscopy}

Chromosomes for high-resolution scanning electron microscopy were prepared from the TM4 cells according to standard cytogenetic techniques [Guttenbach et al., 2001], stored in standard acetic acid:methanol (3:1) fixative, followed by chromosome isolation according to the drop/cryo technique [Martin et al., 1994]. Chromosomes were stained for DNA with platinum blue according to Wanner and Formanek [1995]. The preparations were analyzed with a Hitachi S-4100 field emission scanning electron microscope. Back-scattered electrons were monitored at $15 \mathrm{kV}$ with an Autrata detector of the YAG type.
Confocal Laser Scanning Microscopy

Interphase cell nuclei were obtained from growing TM4 Sertoli cells, hypotonically treated and fixed according to standard techniques [Guttenbach et al., 2001]. FISH with the DOP-PCR products was as with the metaphase chromosomes (see above). Images were acquired by confocal laser scanning microscopy using a LSM 310 (Carl Zeiss, Jena) with an argon-krypton laser (488- and 543-nm lines) for simultaneous dual-color detection. A total of 30 interphase nuclei with distinct hybridization signals were examined.

\section{Results and Discussion}

\section{Karyotypes}

In agreement with our previous study [Guttenbach et al., 2001], the karyotypes of TM4 mouse Sertoli cells show a distinctly increased chromosome number (figs. 1, 2). The majority of cells contain 70-95 chromosomes (fig. 2). In some few metaphases, the chromosome number exceeds 100 (fig. 1). Most chromosomes show the usual telocentric morphology of mouse autosomes and X chromosome with distinct $\mathrm{C}$-banding confined to their centromeric regions. In 2 out of the $50 \mathrm{C}$-banded metaphases analyzed, a Y chromosome was identified on the basis of its size and typical dark staining (not shown). Again, the majority of metaphases show the presence of a single marker chromosome $\mathrm{m}_{1}$ and $\mathrm{m}_{3}$, and varying numbers of marker chromosomes $\mathrm{m}_{2}, \mathrm{~m}_{4}$ and $\mathrm{m}_{5}$ (figs. 1,2 ). It was already demonstrated by spectral karyotyping (SKY) that the large telocentric marker chromosome $\mathrm{m}_{1}$ originated by a reciprocal 1;3 translocation, and that the metacentric marker chromosomes $\mathrm{m}_{2}$ and $\mathrm{m}_{3}$ are isochromosomes 11 and 18 , respectively. The isochromosome 18 is of complex origin as shown by the subterminally located interstitial C-bands in both arms (fig. 1a). SKY could not unravel the origin of the small different-sized heterochromatic marker chromosomes $\mathrm{m}_{4}$ and $\mathrm{m}_{5}$. Active nucleolus organizer regions (NORs) are present at the ends of both arms in the metacentric marker chromosome $\mathrm{m}_{3}$ and in a terminal position of the small marker chromosome $\mathrm{m}_{4}$ [Guttenbach et al., 2001].

In addition to the confirmed marker chromosomes $\mathrm{m}_{1}-\mathrm{m}_{5}, 2$ further marker chromosomes, $\mathrm{m}_{6}$ and $\mathrm{m}_{7}$, were

Fig. 1. Karyotypes of TM4 Sertoli cell metaphases showing Cbands (a), DAPI staining (b) and FISH with the repetitive DNA probe obtained from $\mathrm{m}_{4}$ and $\mathrm{m}_{5}$ marker chromosomes (c). The normal telocentric chromosomes are arranged according to decreasing sizes. The marker chromosomes $m_{1}-m_{5}$ are framed.

(For figure see next page.)

Schmid/Guttenbach/Steinlein/Wanner/ Houben 

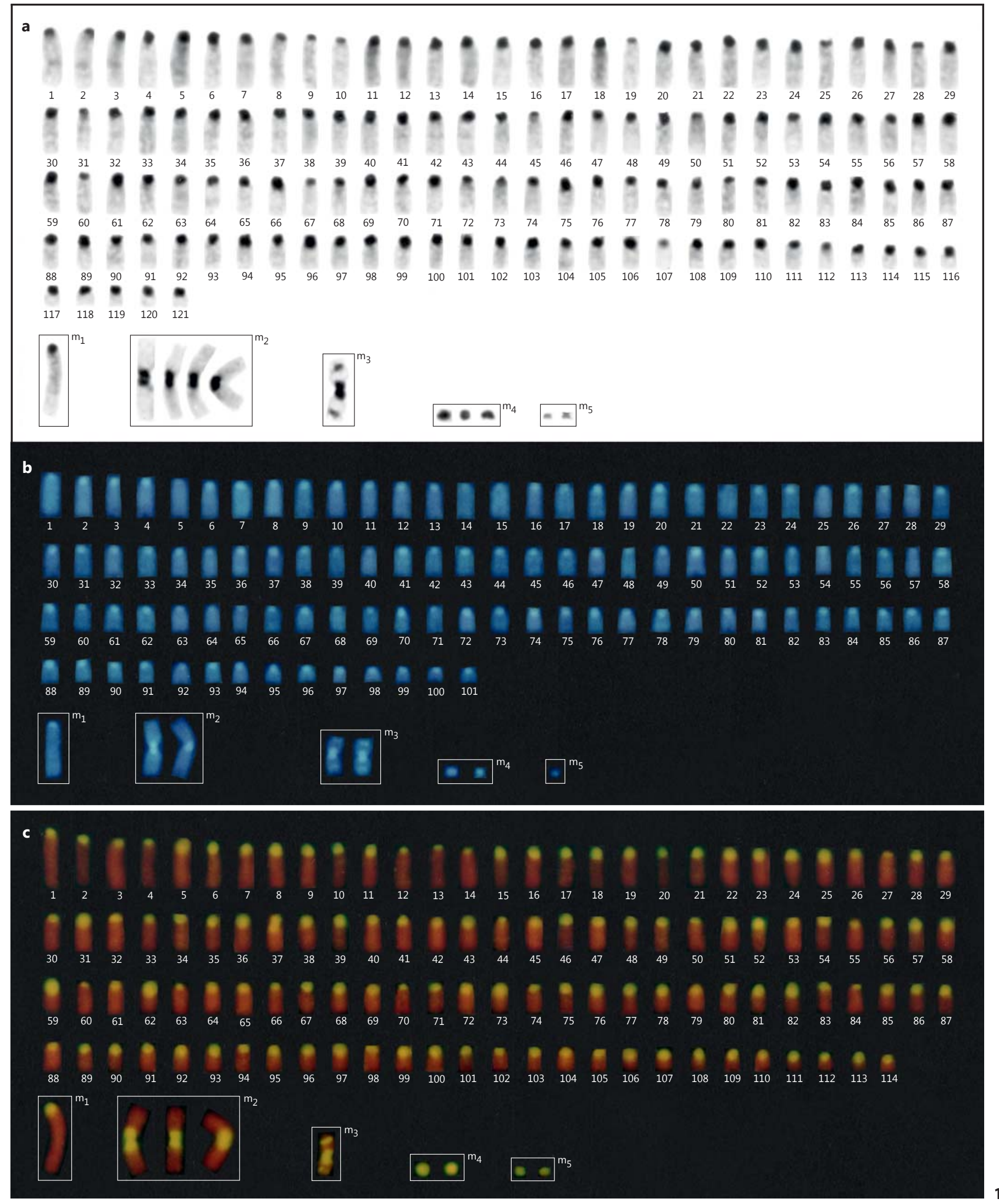

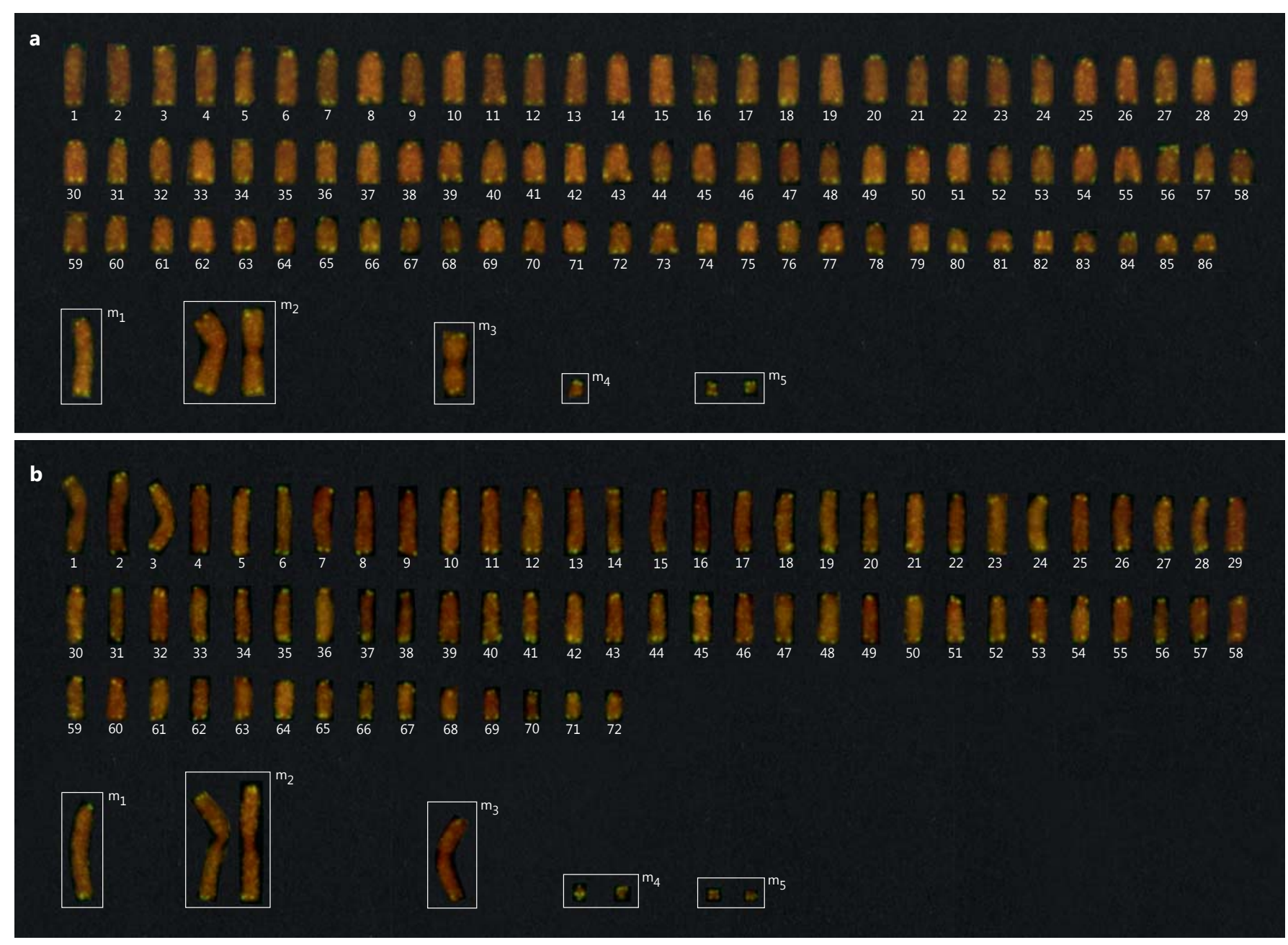

Fig. 2. Two karyotypes of TM4 Sertoli cell metaphases showing telomeric hybridization signals in the chromosomes after FISH with the (GGGTTA) 7 and (TAACCC) 7 oligomers. The normal telocentric chromosomes are arranged according to decreasing sizes. The marker chromosomes $m_{1}-m_{5}$ are framed.

detected in the present study (fig. 3). These were found in 1 each of the 100 metaphases examined. Marker chromosome $\mathrm{m}_{6}$ is a telocentric element with the usual heterochromatic centromeric region and additional constitutive heterochromatin located interstitially in the proximal half of the chromosome. Marker chromosome $\mathrm{m}_{7}$ is the largest chromosome found in TM4 cells (about twice the size of an $\mathrm{m}_{3}$ marker chromosome). It contains a heterochromatic centromeric region, a small interstitial heterochromatic band in the proximal half of the chromosome, and a very large heterochromatic segment in the complete terminal third of the chromosome. SKY analysis was not performed on the $\mathrm{m}_{6}$ and $\mathrm{m}_{7}$ marker chromosomes.
As expected, direct staining with the AT base pair-specific DNA ligand DAPI yields brightly fluorescing centromeric heterochromatin in all normal as well as in the aberrant marker chromosomes $m_{1}-m_{5}$ of the TM4 Sertoli cells (fig. 1b). Furthermore, both interstitially located subterminal C-bands in the marker chromosome $\mathrm{m}_{3}$ do also exhibit a bright DAPI fluorescence. DAPI-positive constitutive heterochromatin is characteristic for all autosomes and the $\mathrm{X}$ chromosome of the mouse and a strong indication of AT base pair richness of the repetitive DNA sequences located in these heterochromatic regions [Sumner, 1990]. 


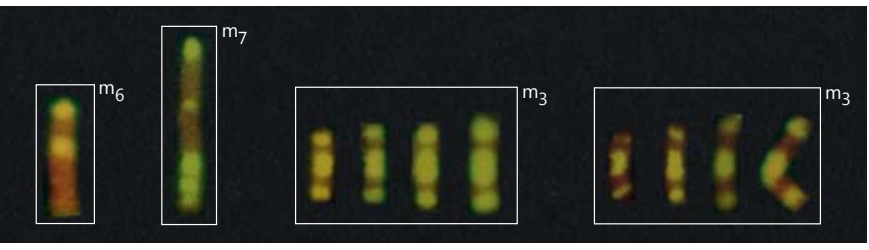

Fig. 3. Selected marker chromosomes $m_{6}$ and $m_{7}$ found in TM4 Sertoli cell metaphases after FISH with the repetitive DNA probe obtained from $\mathrm{m}_{4}$ and $\mathrm{m}_{5}$ marker chromosomes. For size comparisons, several marker chromosomes $\mathrm{m}_{3}$ are included.

\section{Chromosome Microdissection, DOP-PCR and FISH}

FISH of the DNA probe obtained by microdissection and DOP-PCR from $\mathrm{m}_{4}$ and $\mathrm{m}_{5}$ marker chromosomes on metaphases of TM4 Sertoli cells distinctly labels the heterochromatic regions in all normal chromosomes as well as in the aberrant marker chromosomes $m_{1}-m_{7}$ (figs. $1 c$, 3 ). In the small heterochromatic $\mathrm{m}_{4}$ and $\mathrm{m}_{5}$ marker chromosomes, the hybridization signal covers the chromosomes completely. The fact that the hybridization of the DNA probe is confined to the constitutive heterochromatin of the chromosomes clearly demonstrates that the small different-sized marker chromosomes $\mathrm{m}_{4}$ and $\mathrm{m}_{5}$ are centromeric fragments derived from normal chromosomes.

In the mouse, 2 different classes of reiterated DNA sequences are located in the centromeric regions of the chromosomes. These consist of the major satellite repeats (6 Mb, 234-bp units) and the minor satellite repeats ( $\sim 600$ $\mathrm{kb}, 120$-bp units) [Choo, 1997]. Major satellite repeats are located in the pericentrometric heterochromatin, whereas the minor satellite repeats are restricted to the centromeric constriction [Wong and Rattner, 1988; Joseph et al., 1989]. With certainty, the $\mathrm{m}_{4}$ and $\mathrm{m}_{5}$ marker chromosomes in the TM4 Sertoli cells contain both classes of repeats.

FISH of the (GGGTTA) $)_{7}$ and (TAACCC) ${ }_{7}$ oligomers on metaphases of TM4 Sertoli cells demonstrates telomeric signals at the telomeric ends of all normal and marker chromosomes $m_{1}-m_{3}$ (fig. 2). Interstitially located hybridization signals are not detectable, though the FISH technique applied would probably not demonstrate the presence of very short $(<1 \mathrm{~kb})$ stretches of the repetitive (TTAGGG) $)_{\mathrm{n}}$ sequence. In the majority of the small $\mathrm{m}_{4}$ and $\mathrm{m}_{5}$ marker chromosomes, clear telomeric labeling is found (fig. 2). In most preparations, 4 hybridization signals per $\mathrm{m}_{4}$ and $\mathrm{m}_{5}$ marker chromosome, corresponding to the 2 chromatids, are detectable (fig. 2a). However, in some metaphases, the telomeric signals in these small

Cytogenetic Characterization of the TM4

Mouse Sertoli Cell Line. II. marker chromosomes approach to each other and fuse, mimicking the presence of centromeric hybridization. In the $\mathrm{m}_{4}$ and $\mathrm{m}_{5}$ marker chromosomes of some few metaphases no hybridization signals at all were seen. It cannot be decided whether this actually is due to the absence of the canonical (TTAGGG) ${ }_{n}$ sequence, or merely because the number of these telomeric repeats is below the threshold of detectability.

In conclusion, the small $\mathrm{m}_{4}$ and $\mathrm{m}_{5}$ marker chromosomes do not have a ring structure. They are linear elements containing a centromeric region composed of heterochromatin with highly repetitive DNA sequences (major and minor satellite repeats) flanked by 2 intact telomeric regions with reiterated (TTAGGG) n $_{\mathrm{n}}$ sequences. Additionally, the marker chromosome $\mathrm{m}_{4}$ contains a site with transcriptionally active $18 \mathrm{~S}+28 \mathrm{~S}$ rDNA sequences (NOR). Size measurements of the $\mathrm{m}_{4}$ and $\mathrm{m}_{5}$ marker chromosomes at the electron microscopic level yielded a diameter of $0.5-1 \mu \mathrm{m}$ (fig. 5). These minute marker chromosomes replicate, divide and segregate mitotically like the much larger normal mouse chromosomes from which they have broken off. They behave like self-perpetuating chromosomal structures that arose de novo from normal chromosomes by a complex intrachromosomal event. They are certainly not chromatin structures containing socalled neocentromeres. Such centromeres can originate in non-centromeric (often euchromatic) chromosome fragments when a chromosome break or rearrangement separates this fragment from the rest of the chromosome.

\section{Metaphase Arrangement of Marker Chromosomes $m_{4}$} and $m_{5}$

As was previously apparent in TM4 Sertoli cells [Guttenbach et al., 2001], the 2 different-sized marker chromosomes $\mathrm{m}_{4}$ and $\mathrm{m}_{5}$ show a remarkable non-random position in the metaphase stage. About $60 \%$ of these microchromosomes are closely associated with the centromeric region of any of the other chromosomes. Figure 4 shows several examples of such centromeric associations as they are observed after FISH with the repetitive DNA probe obtained from $\mathrm{m}_{4}$ and $\mathrm{m}_{5}$ marker chromosomes. In some metaphases, these marker chromosomes come into direct contact with the centromeric region of another chromosome (e.g. fig. 4e, f, i), in other cells they maintain a distance, which approximately corresponds to half of the size of the marker chromosome itself (e.g. fig. 4a-c).

As discussed by Guttenbach et al. [2001], the conspicuous tight association of the small $\mathrm{m}_{4}$ marker chromosome to the centromeric regions of the normal telocentric 

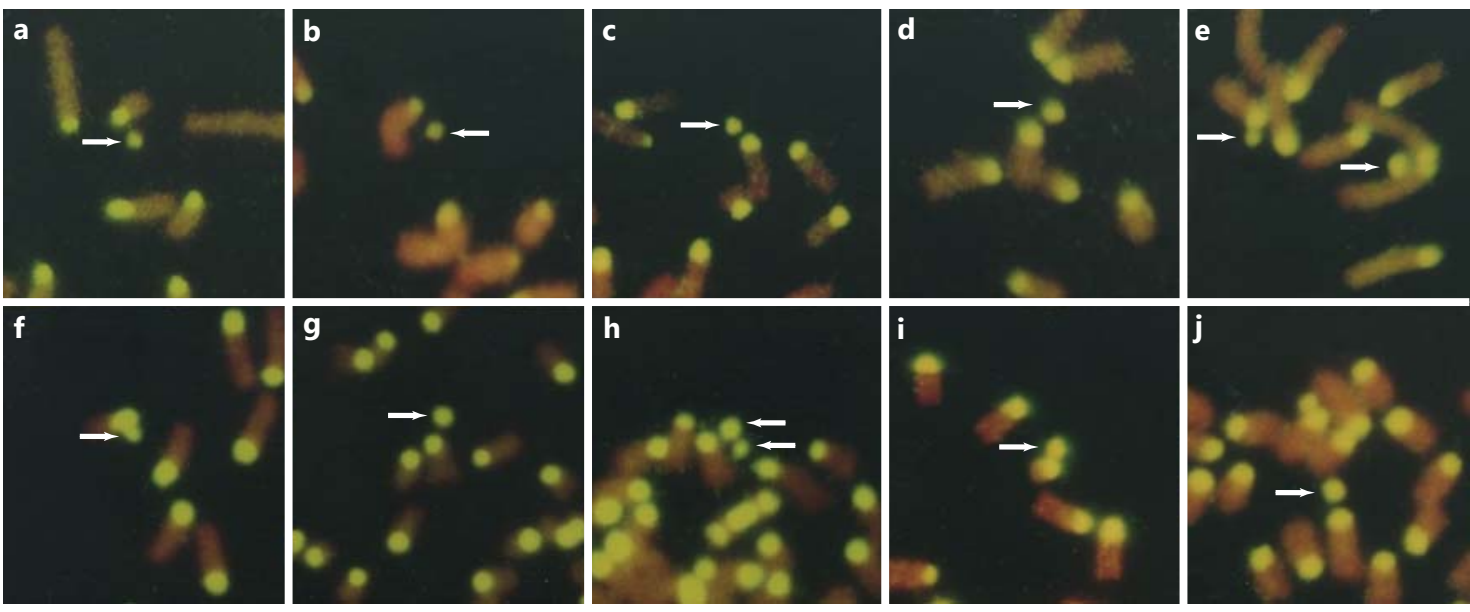

Fig. 4. Examples of centromeric associations (arrows) between the heterochromatic $\mathrm{m}_{4}$ and $\mathrm{m}_{5}$ marker chromosomes and the centromeres of normal telocentric chromosomes in metaphases of TM4 Sertoli cells.

chromosomes may partially be due to the presence of active NORs in this marker chromosome and in the paracentromeric regions of the normal telocentric mouse autosomes 12 and 15-19 [Dev et al., 1977]. However, the $\mathrm{m}_{4}$ marker is also associated with the centromeric region of the markers $\mathrm{m}_{1}$ and $\mathrm{m}_{2}$ which do not contain NORs (fig. 4e). Furthermore, there are also tight associations between the different-sized markers $\mathrm{m}_{4}$ and $\mathrm{m}_{5}$. Finally, the marker chromosome $m_{5}$ is equally involved in centromeric associations with the normal telocentric chromosomes (fig. 4a, c, f). Therefore, the non-random location of the $\mathrm{m}_{4}$ and $\mathrm{m}_{5}$ marker chromosomes is further evidence for the actual existence of a centromeric association. This phenomenon was discovered in chromosome preparations of a human patient with CREST scleroderma and a supernumerary microchromosome consisting of an active centromere and some adjacent constitutive heterochromatin derived from chromosome 11 [Schmid et al., 1989; Haaf et al., 1992]. Centromeric association was later confirmed in other patients also exhibiting additional microchromosomes in their cells [Rivera et al., 1993, 1997; Felbor et al., 2002; Klein et al., 2012], as well as in human tumor cells [Haaf and Schmid, 1989].

Centromeric association of minute marker chromosomes to centromeric regions of normal chromosomes can best be explained by ectopic pairing of constitutive heterochromatin [Comings, 1980; Manuelidis, 1990; Haaf and Schmid, 1991]. Indeed, one of the general features of heterochromatin is its tendency for different heterochromatic regions to enter into non-specific temporary or permanent associations as was first shown in He- miptera [Slack, 1939; Schrader, 1941]. In polytene Drosophila nuclei, the pericentromeric heterochromatin of all chromosomes becomes permanently fused to form a large chromocenter, and many intercalary heterochromatic bands do also demonstrate ectopic pairing [Slizynski, 1946; Kaufmann and Iddles, 1963]. In interphase nuclei of a variety of mouse tissues, ectopic pairing of centromeric heterochromatin of different chromosomes results in the formation of large, highly condensed clusters [Hsu et al., 1971; Rae and Francke, 1972]. Ectopic pairing in human lymphocytes occurs most frequently between the heterochromatin of homologous chromosomes but also between non-homologous chromosomes, although the first type is, in statistical terms, more frequent [Haaf et al., 1986; Klein et al., 2012]. The existence of repetitive DNA-containing physical connections between metaphase chromosomes has been demonstrated to occur in mouse and human cell lines by Kuznetsova et al. [2007]. In mitotic metaphase chromosomes of amphibians, chromatin connections were found between heterochromatic regions in telomere-telomere, centromere-centromere and centromere-telomere configurations [Schmid et al., 2010]. In the present study, scanning electron micrography of TM4 metaphases stained with DNA-specific platinum blue also showed visible DNAprotein bridges connecting the centromeric or paracentromeric regions of normal chromosomes and associated small marker chromosomes $\mathrm{m}_{4}$ and $\mathrm{m}_{5}$ (fig. 5). It seems conceivable, but not yet experimentally proven, that ectopic pairing is mediated by a complete (or at least partial) homology of the base pairs in the repetitive DNA of het- 

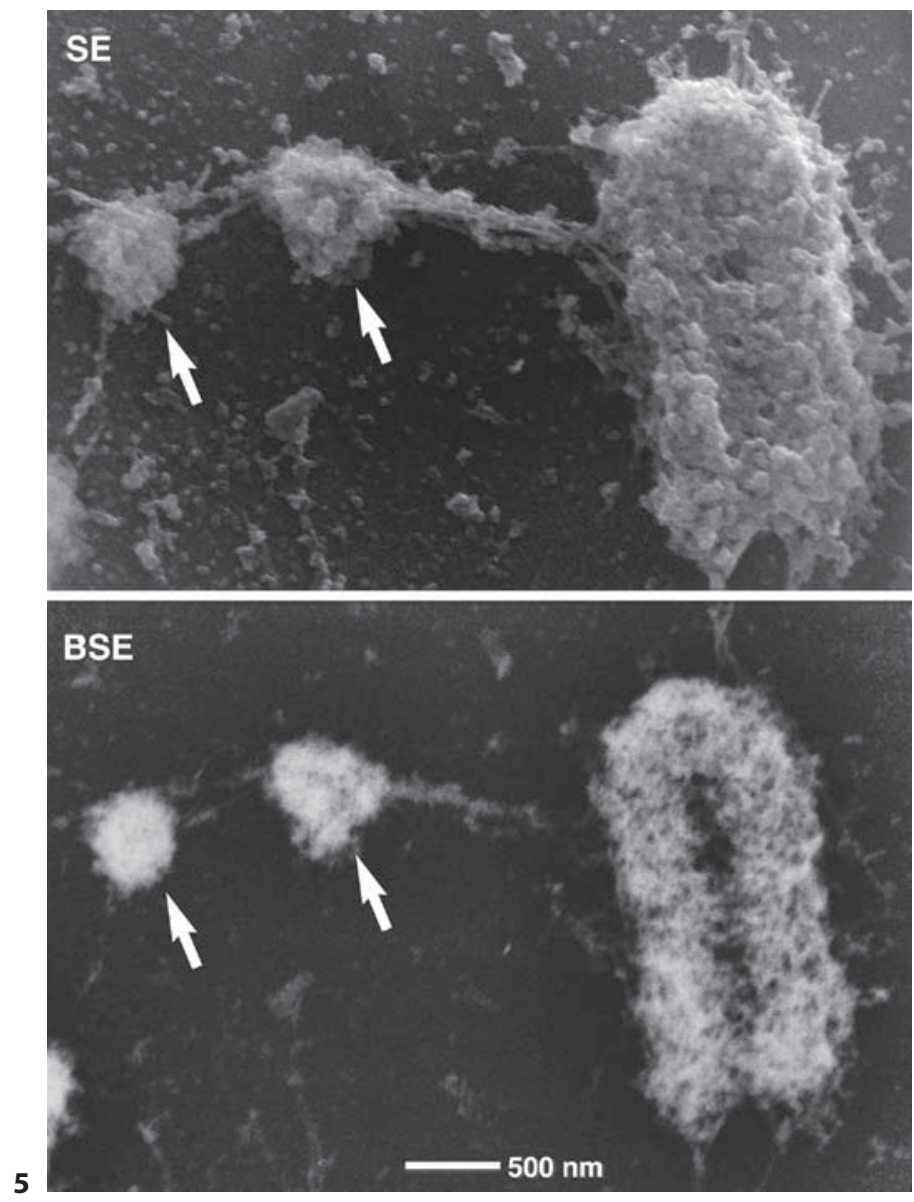

erochromatin. The ectopic pairing of minute heterochromatic marker chromosomes at the heterochromatin of normal chromosomes must originate in the interphase nuclei. In dividing cells, this close physical contact persists from interphase until the stage of metaphase where it becomes apparent as centromeric association.

\section{Morphology of TM4 Sertoli Cell Nuclei}

Normal Sertoli cells in adult mice can be unequivocally identified because of their characteristic morphological appearance, showing a central large nucleolus with a clustering of the centromeric heterochromatin in round chromocenters at its periphery [Hsu et al., 1971; Brinkley et al., 1986]. A systematic analysis revealed that $84.2 \%$ of the normal Sertoli cell nuclei contain 2 chromocenters, usually located at diametrically opposed sides of the nucleolus; in $13.6 \%$ there is only 1 large chromocenter, and in only $2.2 \%$ there are 3 chromocenters. Neither nuclei with more than 3 chromocenters nor irregularly shaped chromocenters can be found [Guttenbach et al., 1996].

Cytogenetic Characterization of the TM4 Mouse Sertoli Cell Line. II.
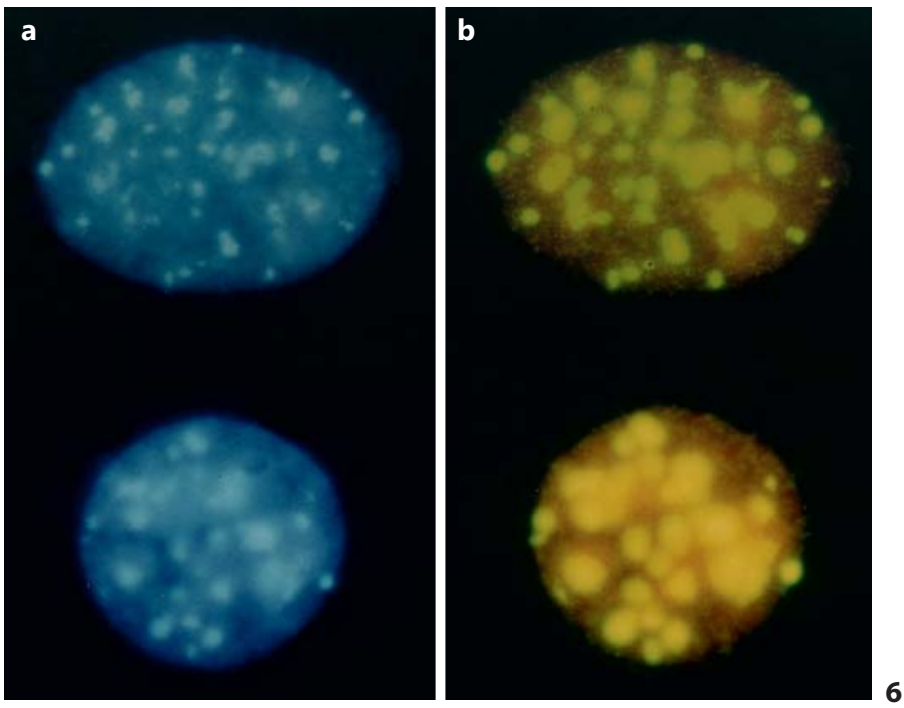

Fig. 5. Scanning electron micrographs of chromosomes stained with DNA-specific platinum blue. The secondary electron (SE) image (DNA + protein) shows the topography of a large telocentric chromosome and 2 microchromosomes of the $\mathrm{m}_{5}$ type (arrows). The backscattered electrons (BSE) image reveals distribution of DNA by bright signals. Note the chromatin bridges between the 2 microchromosomes and between the right microchromosome and the centromeric region of the telocentric chromosome.

Fig. 6. Two TM4 Sertoli cell nuclei stained with DAPI (a) and subsequent FISH with the repetitive DNA probe obtained from $\mathrm{m}_{4}$ and $\mathrm{m}_{5}$ marker chromosomes (b). Note the dispersed arrangement of the centromeric chromosome regions in the nuclei.

This typical nuclear architecture is distinctly absent in TM4 Sertoli cells. As shown by simultaneous DAPI staining and FISH with the repetitive centromeric DNA probe, the centromeric regions of the chromosomes do not associate into large chromocenters but are dispersed over the entire nuclei (fig. 6). A large, centrally located nucleolus is not apparent in the DAPI stained nuclei. The same result is achieved using FISH with the repetitive centromeric DNA probe and confocal laser scanning microscopy where only partial fusions of centromeric heterochromatic regions become apparent (fig. 7).

It is conceivable that the atypical nuclear architecture found in TM4 Sertoli cells is due to the fact that this cell line was initiated from immature testes of $B A L B / c$ mice in which the characteristic structure of the Sertoli cell nuclei apparently has not yet been formed. It must be considered that TM4 Sertoli cells are nontumorigenic as shown by their inability to form tumors in syngeneic nude mice. Therefore, it can be excluded that a loss of the characteristic Sertoli cell nuclei architecture is the result

Cytogenet Genome Res 2015;147:135-143 
Fig. 7. Confocal laser scanning microscopy of a TM4 Sertoli cell nucleus showing FISH with the repetitive DNA probe obtained from $\mathrm{m}_{4}$ and $\mathrm{m}_{5}$ marker chromosomes.

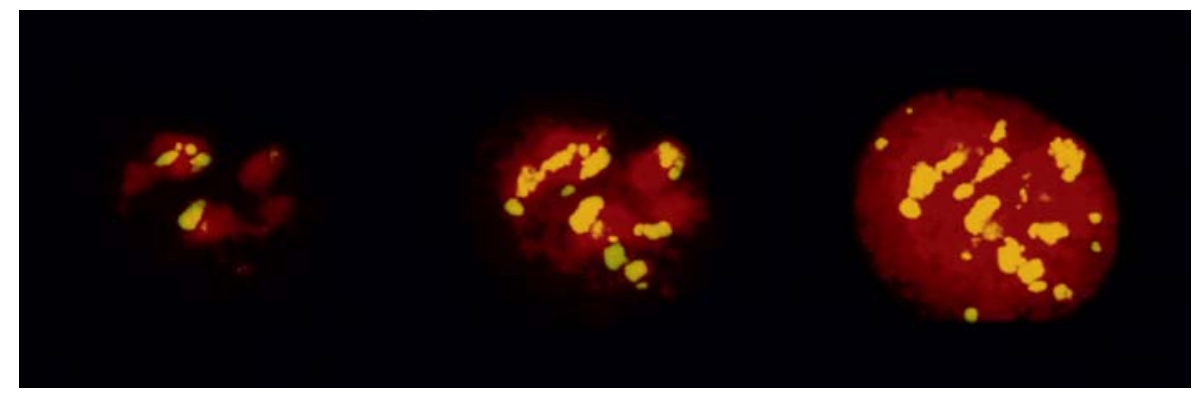

of a malignant transformation during cell culture. In this regard, it would be of interest to examine the interphase chromosome arrangement in other Sertoli cell lines derived from prepubertal and adult mice [Hofmann et al., 1992; Peschon et al., 1992; Boekelheide et al., 1997].

\section{Disclosure Statement}

The authors have no conflicts of interest to declare.

\section{References}

Akerstrom VL, Walters MR: Physiological effects of 1,25-dihydroxyvitamin D3 in TM4 Sertoli cell line. Am J Physiol 262:E884-E890 (1992).

Boekelheide K, Lee JW, Hall SJ, Rhind NR, Zaret KS: A tumorigenic murine Sertoli cell line that is temperature-sensitive for differentiation. Am J Pathol 143:1159-1168 (1997).

Braunhut SJ, Rufo GA, Ernisee BJ, Zheng WX, Bellvé AR: The seminiferous growth factor induces proliferation of TM4 cells in serum-free medium. Biol Reprod 42:639-648 (1990).

- Brinkley BR, Brenner SL, Hall JM, Tousson A, Balczon RD, Valdivia MM: Arrangements of kinetochores in mouse cells during meiosis and spermatogenesis. Chromosoma 94:309317 (1986).

Choo KHA: The Centromere (Oxford University Press, Oxford 1997).

-Comings D: Arrangement of chromatin in the nucleus. Hum Genet 53:131-143 (1980).

Dev VG, Tantravahi R, Miller DA, Miller OJ: Nucleolus organizers in Mus musculus subspecies and in the RAG mouse cell line. Genetics 86:389-398 (1977)

Felbor U, Rutschow D, Haaf T, Schmid M: Centromeric association of chromosome 16- and 18-derived microchromosomes. Hum Genet 111:16-25 (2002).

Guttenbach M, Martínez-Expósito MJ, Engel W, Schmid M: Interphase chromosome arrangement in Sertoli cells of adult mice. Biol Reprod 54:980-986 (1996).

- Guttenbach M, Steinlein C, Engel W, Schmid M Cytogenetic characterization of the TM4 mouse Sertoli cell line. I. Conventional banding techniques, FISH and SKY. Cytogenet Cell Genet 94:71-78 (2001).
Haaf T, Schmid M: Centromeric association and non-random distribution of centromeres in human tumour cells. Hum Genet 81:137-143 (1989).

Haaf T, Schmid M: Chromosome topology in mammalian interphase nuclei. Exp Cell Res 192:325-332 (1991).

Haaf T, Steinlein K, Schmid M: Preferential somatic pairing between homologous heterochromatic regions of human chromosomes. Am J Hum Genet 38:319-329 (1986).

Haaf T, Sumner AT, Köhler J, Willard HF, Schmid M: A microchromosome derived from chromosome 11 in a patient with the CREST syndrome of scleroderma. Cytogenet Cell Genet 60:12-17 (1992).

$\checkmark$ Hofmann MC, Narisawa S, Hess RA, Millán JL: Immortalization of germ cells and somatic testicular cells using the SV40 large T antigen. Exp Cell Res 201:417-435 (1992).

Hsu TC, Cooper JEK, Mace ML Jr, Brinkley BR: Arrangement of centromeres in mouse cells. Chromosoma 34:73-87 (1971).

-Joseph A, Mitchell AR, Miller OJ: The organization of the mouse satellite DNA at centromeres. Exp Cell Res 183:494-500 (1989).

Kaufmann BP, Iddles MK: Ectopic pairing in salivary gland chromosomes of Drosophila melanogaster. I. Distributional patterns in relation to puffing. Port Acta Biol A 7:225-248 (1963).

-Klein E, Manvelyan M, Simonyan I, Hamid AB, Guilherme RS, et al: Centromeric association of small supernumerary marker chromosomes with their sister-chromosomes detected by three dimensional molecular cytogenetics. Mol Cytogenet 5:15 (2012).
Kumi-Diaka J, Rodriguez R, Goudaze G: Influence of genistein (4',5,7-trihydroxyisoflavone) on the growth and proliferation of testicular cell lines. Biol Cell 90:349-354 (1998).

Kuznetsova IS, Enukashvily NI, Noniashvili EM, Shatrova AN, Aksenov ND, et al: Evidence for the existence of satellite DNA-containing connection between metaphase chromosomes. J Cell Biochem 101:1046-1061 (2007).

Manuelidis L: A view of interphase chromosomes. Science 250:1533-1540 (1990).

- Martin R, Busch W, Herrmann RG, Wanner G: Efficient preparation of plant chromosomes for high-resolution scanning electron microscopy. Chromosome Res 2:411-415 (1994).

Mather JP: Establishment and characterization of two distinct mouse testicular epithelial cell lines. Biol Reprod 23:243-252 (1980).

Mather JP, Zhuang LZ, Perez-Infante V, Phillips DM: Culture of testicular cells in hormonesupplemented serum-free medium. Ann NY Acad Sci 383:44-68 (1982).

Meyne J, Baker RJ, Hobart HH, Hsu TC, Ryder OA, et al: Distribution of non-telomeric sites of the (TTAGGG) ${ }_{n}$ telomeric sequence in vertebrate chromosomes. Chromosoma 99:3-10 (1990).

Moyzis RK, Buckingham JM, Cram LS, Dani M, Deaven LL, et al: A highly repetitive DNA sequence, (TTAGGG) $)_{\mathrm{n}}$, present at the telomeres of human chromosomes. Proc Natl Acad Sci USA 85:6622-6626 (1988). 
Musa FR, Takenaka I, Konishi R, Tokuda M: Effects of luteinizing hormone, follicle-stimulating hormone, and epidermal growth factor on expression and kinase activity of cyclindependent kinase 5 in Leydig TM3 and Sertoli TM4 cell lines. J Androl 21:392-402 (2000).

Peschon JJ, Behringer RR, Cate RL, Harwood KA, Idzerda RL, et al: Directed expression of an oncogene to Sertoli cells in transgenic mice using Mullerian inhibiting substance regulatory sequences. Mol Endocrinol 6:1403-1411 (1992).

-Pich U, Houben A, Fuchs J, Meister A, Schubert I: Utility of DNA amplified by degenerate oligonucleotide-primed PCR (DOP-PCR) from the total genome and defined chromosomal regions of field bean. Mol Gen Genet 243: 173-177 (1994).

Rae PMM, Francke WW: The interphase distribution of satellite DNA-containing heterochromatin in mouse nuclei. Chromosoma 39: 443-456 (1972).

-Rivera H, Dominguez MG, Vasquez AI, Ramos AL, Fragoso R: Centromeric association of a microchromosome in a Turner syndrome pa- tient with a pseudodicentric Y. Hum Genet 92:522-524 (1993).

Rivera H, Dominguez MG, Vasquez AI, MejiaBaltodano G: A further microchromosome with centromeric association. Genet Couns 8: 323-326 (1997).

Schmid M, Haaf T, Schindler D, Meurer M: Centromeric association of a microchromosome. A new category of non-random arrangement of metaphase chromosomes. Hum Genet 81: 127-136 (1989).

Schmid M, Steinlein C, Bogart JP, Feichtinger W, León P, et al: The chromosomes of terraranan frogs. Insights into vertebrate cytogenetics. Cytogenet Genome Res 130/131:1-568 (2010).

Schrader F: Heteropycnosis and non-homologous association of chromosomes in Edessa irrorata (Hemiptera, Heteroptera). J Morphol 69:587-607 (1941).

Slack HD: The association of non-homologous chromosomes in Corixidae (Hemiptera, Heteroptera). Proc R Soc Edinb 58:192-212 (1939).

Slizynski BM: Ectopic pairing and the distribution of heterochromatin in the X-chromosome of salivary gland nuclei of Drosophila melanogaster. Proc R Soc Edinb Biol 62:114119 (1946).

Sumner AT: A simple technique for demonstrating centromeric heterochromatin. Exp Cell Res 75:304-306 (1972).

Sumner AT: Chromosome Banding (Unwin Hyman, London 1990).

Telenius H, Carter NP, Bebb CE, Nordenskjold M, Ponder BAJ, Tunnacliffe A: Degenerate oligonucleotide-primed PCR: general amplification of target DNA by a single degenerate primer. Genomics 13:718-725 (1992).

Wanner G, Formanek H: Imaging of DNA in human and plant chromosomes by high-resolution scanning electron microscopy. Chromosome Res 3:368-374 (1995).

Wong AK, Rattner JB: Sequence organization and cytological organization of the minor satellite of mouse. Nucleic Acids Res 16:11645-11661 (1988).

Zhengh WX, Butwell TJ, Heckert L, Griswold MD, Bellve AR: Pleiotropic actions of the seminiferous growth factor on two testicular cell lines: comparisons with acidic and basic fibroblast growth factors. Growth Factors 3: 73-82 (1990). 